\title{
EXTERNAL SHOCKS AND POVERTY: \\ HOW RECESSION IN EUROPE, JAPAN, AND CHINA AFFECTS THE INDONESIAN POOR
}

\author{
Arief Anshory Yusuf
}

\begin{abstract}
This paper analyzes the effect of a recession in Europe, Japan, and China on the poverty in Indonesia. We use the GTAP model and the INDONESIA-E3 model to examine the impact of a 2 percent GDP decline in these three countries on the poverty in Indonesia. The results suggest a negative impact on Indonesia's GDP, mainly through the trade-linkages but with a small magnitude. The main reason for this finding has to do with the low dependency of Indonesia on international trade. The shock also slightly increases the poverty in Indonesia with a small magnitude. Across the household types, the negative effects of these recession goes mainly to higher income households since large part of their incomes comes from the capital and skill-intensive sectors. The poor household types are likely to be the first to lose their jobs in the event of this recession, since they are less skilled. These findings urge the Indonesian government to lunch employment programs to ensure the employment continuity for these unskilled laborers in the anticipation of a global recession particularly originating from these three countries.
\end{abstract}

Keywords: Recession, GTAP, Computable General Equilibrium, INDONESIA-E3.

JEL Classification : E37, F15

1 Dr. Arief Anshory Yusuf is the Director of the Center for Economics and Development Studies (CEDS) of Universitas Padjadjaran, Indonesia. He is also an Adjunct Fellow at the Australian National University and a Visiting Fellow at King's College London. Email: arief.yusuf@fe.unpad.ac.id 


\section{INTRODUCTION}

From the start of the "New Order" government in 1966 up until 1997, broad-based economic development in Indonesia led to an impressive four-fold increase in per capita income. As a result, poverty in the country fell dramatically. Between 1976 and 1996 the number of poor people in Indonesia declined from 54.2 to 22.5 million.

However, the Asian Financial Crisis in 1997 brought a sharp halt to this economic miracle. Between 1997 and 1998 annual GDP growth in Indonesia fell by 13 percent and the incidence of poverty increased by 7 percent. The events of 1997-98 were a painful reminder of just how vulnerable the Indonesian economy was to external shocks coming from abroad.

For this reason, the current recession in Europe raises deep concerns about the possible impact of these events on the Indonesian economy. However, to date there has not been any quantitative analysis of the possible impact of these events on economic growth and poverty in Indonesia. The purpose of this paper is, therefore, to provide a modeling-based assessment of the possible effects of a recession in Europe, Japan and China - EJC countries, for short -- on Indonesia.

The objective of this paper is to use general equilibrium models to quantitatively assess the impact of the current recession in Europe, Japan and China on Indonesian poverty. It is expected that the results from such a general equilibrium analysis will give us important insights on how to design appropriate policy instruments for protecting the Indonesian economy from external disturbances.

The next section of this paper outlines the theory and the structure of the model. Section three outlines the data and the methodology, including the scenario of simulation. Section four provides result and analysis, while section five gives conclusion and the policy implications.

\section{THEORETICAL FRAMEWORK AND EMPIRICAL LITERATURE \\ 2.1. How external shock can affect poverty}

It should be clear that what it means by external shock is in the context of exogenous change from the country's persepective. In this case, those shocks can be a recession in a particular country, a group of countries, or one or some regions. The shocks can also be international price of commodities determined in the world market exogenous to the perspective a a particular country or the assumption of Indonesia being a small open economy.

Poverty should also be defined clearly. There are many dimension of poverty, but in this particular study, the focus is on expenditure poverty which is quantitatively measured as head-count poverty incidence, which can be written as Foster, Greer, Thorbecke (FGT) Index of poverty initially developed by Foster et al (1984): 


$$
P_{\alpha}=\frac{1}{N} \sum_{i=1}^{H}\left(\frac{z-y_{i}}{z}\right)^{\alpha}
$$

Where $P$ is the poverty indicator, $N$ is the number of population, $H$ is the number of people whose expenditure per person is below the poverty line, $y$ is a vector of expenditure per person in increasing order, $z$ is the poverty line, $\alpha \geq 0$ is a sensitivity parameter. When $\alpha=1$ this become the head-count poverty incidence, which is a proportion of population living below poverty line. This indicator is what will be used throughout this paper.

Figure 1 below illustrate how external shock, like global economic crisis of a particular countries or regions can affect poverty incidence in a national economy.

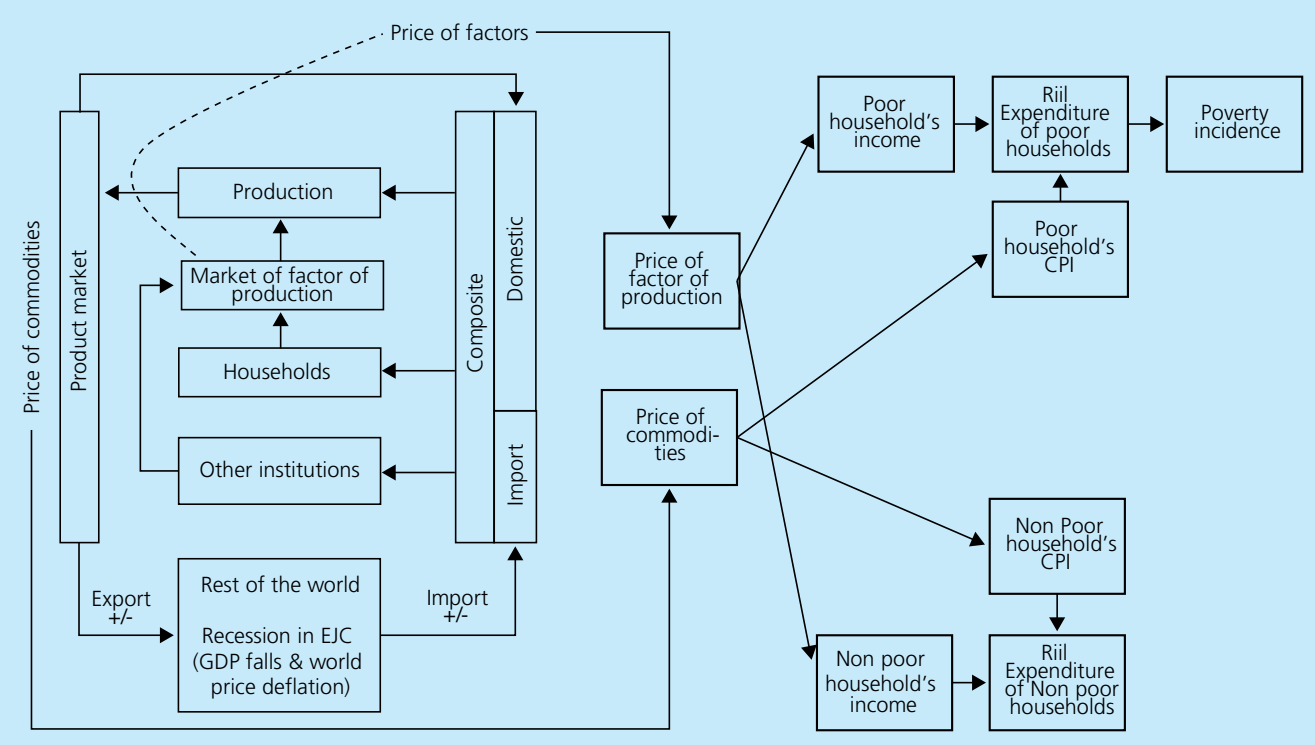

Figure 1.

The effect of external sock on poverty incidence

The impact of an EJC recession on the Indonesian economy can work through various channels, including trade, foreign direct and portfolio investment, and other monetary or financial channels. In this analysis, the focus is on the impact through the trade channel. A recession in the EJC countries will reduce imports and exports from countries like Indonesia. The impact on the Indonesian economy is likely to be negative, and the magnitude of the impact depends largely on the share that these countries have in Indonesian exports. This is the direct 
trade effect. The indirect trade effect is rather unclear. The reduction of imports from Europe, China and Japan will tend to reduce the world prices of commodities. Global deflation like this may reduce Indonesian exports yet increase Indonesian imports.

On the other hand, the decline in the export of goods from the EJC countries may increase the world prices of commodities. To some countries (including Indonesia), this might represent an opportunity to increase exports and to raise world market share. This effect tends to work positively for the Indonesian economy. To complicate things, these effects work differently among different countries, each with a different type of repercussion on the Indonesian economy. Therefore, the overall net impact on the Indonesian economy is difficult to predict and calls for a computable general equilibrium analysis.

The effect on poverty depend on the general equilibrium outcome of prices or new equilibrium prices changed due to the external shocks. There are two kind of prices that at the end will affect through different channels to households. First of all is the price of factors of production will affect household income. The impact on households will be different even though all households face the same price of capital or labor because poor and non-poor households has different composition of household income. Rich households has more capital income than labor, while poor households has more labor income.

Another channels is its impact on price of commodities. Again, although all households face the same price of commodities, the composition of household ecpenditures may differ. Poor household may buy less of travels but more of rice, while rich housholds may buy more of gasoline and other luxurious items.

The final impact on these two channels are on the real expenditure, or expenditure per capita. Poverty incidence then is used based on this real expenditure per person before and after the shocks and the difference is calculated as the impact of external shocks on poverty incidence.

\subsection{Empirical literature}

There have been some studies looking at the of global crisis, particuarly the 2008-2009 crisis, with particular attention on the impact on poverty. In this review, only studies that uses economy-wide model, microsimulation model, or combination of both are reviewed.

Wong, (2012) quantifies the macroeconomic and poverty impacts of the 2008-2009 world economic crisis on Ecuador, including the effects of the main policy responses of the Ecuadorian Government to face the crisis. The main hypothesis highlights the magnitude of two transmission channels: trade and remittances. The study applies a single-country static computable general equilibrium model for Ecuador combined with a microsimulation model. From a distributional point of view, the impacts of the crisis were progressive, affecting more negatively households in the highest income quintile. A key channel of transmission is the fall 
in capital returns and wages of skilled labor. These factors are used intensively in the oil sector, a key sector of the Ecuadorian economy, and one of the hardest hit by the global crisis. There are differentiated poverty impacts: poverty may increase if labor is assumed sector specific, and it may be reduced if labor were mobile.

(Habib, Narayan, Olivieri, \& Sanchez-Paramo, 2010b) develops a simple micro-simulation method, modifying models from existing economic literature, to measure the poverty and distributional impact of macroeconomic shocks by linking macro projections with pre-crisis household data. The approach is then applied to Bangladesh to assess the potential impact of the slowdown on poverty and income distribution across different groups and regions. The poverty headcount rate (based on the upper poverty line) and extreme poverty rate (based on the lower poverty line) are expected to be 0.4 and 0.2 percentage points higher in 2009, respectively, as a result of the crisis.

Using a microsimulation analysis, (Ajwad, Francisco, \& Azam, 2012) look at the distributional impacts of the 2009 financial crisis on households in Latvia. The simulations show that Latvia experienced a sharp rise in poverty, widening of the poverty gap, and a rise in income inequality due to the economic contraction in 2009. The 18 percent contraction in gross domestic product (affecting mainly trade hotels and restaurants, construction, and manufacturing) likely led the poverty head count to increase from 14.4 percent in 2008 to 20.2 percent in 2009.

(Ahmed \& Donoghue, 2010) adopt a macro-micro framework in order to evaluate the impact of a global crisis on the Pakistan economy. They use a 'top-down' approach to combine a static computable general equilibrium model with a microsimulation model. Our results suggest that between 2007 and 2009 the poverty headcount ratio is likely to have increased by almost 80 percent, from 22 to 40 percentage points. However, their results also show that this increase is attributable in part to the fuel and food crisis that preceded the financial crisis. They also indicate a differential impact, with wage increases for farm workers and a decrease in wages for skilled labour.

(Weeks, 2009) using a macroeconomic model finds that the global financial crisis will cause a fall in export earnings in Sierra Leone of approximately fifteen percent in 2009 compared to 2008. He find that this decline in exports earnings could result in a fall in national income of almost ten percent and based on the income distribution in the 2003 household survey, a ten percent decline in national income would increase poverty by twelve percent of th population, or about 600,000 people.

(Habib, Narayan, Olivieri, \& Sanchez-Paramo, 2010a) uses a micro-simulation approach to assess the poverty and distributional effects of the crisis in the Philippines. They find increases in both the level and the depth of aggregate poverty. Income shocks are relatively large in the middle part of the income distribution. They also find that characteristics of people who become poor because of the crisis are different from those of both chronically poor people and the general population. 
(Bibi et al., 2010) evaluate the potential impacts of the 2008/09 global economic crisis on child poverty in Cameroon. A dynamic computable general equilibrium (CGE) model is used to simulate various scenarios of the economic crisis together with policies which respond to the crisis. The study shows that the crisis is projected to lower the real GDP growth rate by 1.3 percentage points in 2009, 0.9 in 2010 and 0.8 in 2011. The crisis would also bring about a $1.05 \%$ increase in the number of children who were poor in monetary terms in 2008 and a $4 \%$ increase in 2009, 2010 and 2011, compared to the situation without a crisis.

In their analysis, (Estrades \& Llambi, 2013) evaluate the impact of the 2008 global economic crisis on Uruguayan economy through two main channels: collapse in global trade and drop in capital flows. They apply a computable general equilibrium model linked to microsimulations to analyze the distributional impacts of these policies and assess their effectiveness. They find that an increase in public investment was the only policy effective in mitigating the negative impact of the crisis on extreme poverty.

In a study which focus on conceptual framework with the application to Vietnam, (Coxhead, Linh, \& Tam, 2012) present a framework for understanding the direct and indirect welfare effects of a global market shock. They quantify transmission of the shock from global indicator prices to domestic markets. Then they use an applied general equilibrium model to simulate the economic effects of the price changes. A recursive mapping to a nationally representative household living standards survey permits them to identify in detail the ceteris paribus effects of the shock on household incomes and welfare. In this analysis, interregional and intersectoral labor market adjustments emerge as key channels transmitting the effects of global price shocks across sectors and among households.

(Corong \& Taningco, 2011) analyzes how the global crisis may have affected the Philippine economy. To the extent that the Philippines is more globally integrated through trade and labor flow channels than the financial sector, it is expected that impact of the global crisis will weigh heavily on the "real" side of the economy. A dynamic computable general equilibriu m (CGE) model linked to a micro-simulation module used trace effects: from the macro-economic to the microeconomic level; from output and factor supplies and demands to commodity and factor prices; and from household incomes to levels of poverty and income distribution. Simulation results suggest that all households experience a significant reduction in real income. Both inequality and poverty increase, with urban dwellers experiencing a higher in crease in poverty relative to their rural counterparts as most export-oriented industries are located in the urban areas and returns to factors intensively used by these industries fall.

To summarize, most of the studies above suggests that global financial crisis affect the poor negatively. However, the magnitude is different; there are exceptions where the impact on poverty is negligible because the crisis affect mostly the rich; and policy responses can have significant impact on the final effect of the crisis. There is however, a methodological gap in most of the studies in how they linked global shocks into the national model. The analysis could 
not really explicitly attribute the shocks to a recession in a specific countries or regions. This is because they only use a national model. In this paper, two models will be used, a global or multi-country model as well as national model to handle poverty. With a global model, we can be more specific on which countries experience a recessions. This is quite important because the impact of a recessions of different countries will have a different impact on the export demand of and the price of the commodities faced by the particular affected countries.

\section{METHODOLOGY}

To estimate the impact of recession in Europe, Japan, and China on Indonesia's economy, we use the Global Trade Analysis Project (GTAP) model, a multi-country, multi-sector general equilibrium model. ${ }^{2}$ For this analysis, the GTAP version7 database is aggregated into 16 regions and 57 sectors. ${ }^{3}$ To simulate a recession in the Euro Zone, the European Union (EU), Japan, China, and in all combined we reduce the endowment of the primary factors. Our primary focus here is on the recession in Europe. However, we add the recession in Japan and China to the analysis to examine the potential impact of a recession in these two countries.

To reflect a reasonable magnitude of recession, we compare the forecasts of country GDP presented in the IMF's World Economic Outlook database of 2009 and 2011. Forecasts of European GDP for 2012, 2013, and 2014 are then compared assuming that the forecast in 2009 is business as usual and the forecast in 2011 already reflects the European crisis. On the basis of this comparison, we calculate that the European recession can be defined as roughly a 2 percent deviation of GDP below baseline. We use this 2 percent deviation to simulate the endowment of primary factors in Europe, Japan, and China.

\subsection{The structure of GTAP Model}

\section{Theoretical structure}

Based on (Hertel, 1997) the theoretical structure of GTAP model can be summarised as follows. Readers who are interested in detailed exposition of the model can directly refer to (Hertel, 1997) or Brockmeier (2001).

The production of each sector in each country is represented by a nested production function which is a combination of a Leontief, Constant Elasticity of Substitution (CES) specification. This kind of a nested or staged production is a convenient way of representing separable, constant returns-to-scale technologies. At the bottom of the inverted tree are the

2 For more explanation of the GTAP model, see Hertel (1997).

3 Oceania, Japan, China, Rest of East Asia, Indonesia, Singapore, Thailand, Rest of SE Asia, North America, Latin America, Euro Zone, Rest of EU, Mid East and North Africa, sub-Saharan Africa, and the rest of the world. 
individual inputs demanded by the firm. Tthe primary factors of production are: land, labor, and capital. Firms also purchase intermediate

- inputs, some of which are produced domestically, and some of which are imported. For imports, the intermediate inputs must be sourced from particular exporters. The strong nature of this kind of multi-country model.

- Regional household (a representative of household for each country) behavior is governed by an aggregate utility function, specified over composite private consumption, composite government purchases, and savings. In the GTAP model we employ a special case of the Stone-Geary utility function, whereby all subsistence shares are equal to zero.

- Government demands follows the Cobb-Douglas utility function.

- Factors are imperfectly mobile in a GTAP model. The mobility of these endowments is described with a constant elasticity of transformation (CET) revenue function.

\section{Database}

In this paper the GTAP database version 7 is used. (Hertel, 1997)describe the database as having 113 regions. The database was constructed from input-output table from each of the 113 countries and combined with a well-developed inter-regional trade flows data. Detailed description of the database including its construction can be found in (Narayanan, Badrie, \& Walmsley, 2008)

\subsection{The structure of INDONESIA-E3 model}

\section{Theoretical structure}

Since the GTAP model cannot analyze distribution results within countries, we use the INDONESIA-E3 model to simulate the effect of an EJC recession on poverty in Indonesia. The strength of this multi-sector, multi-household CGE model of the economy is distributional analysis. Most of its structural features are standard, but its capacity for disaggregation of household structure facilitates analysis of how exogenous shocks affect poverty and inequality.

The theoretical structure of INDONESIA-E3 model is conventional for static general equilibrium models. In particular, the equations in INDONESIA-E3 model represent the following economic behaviour:

- Production sectors minimizing cost of production given a Constant Elasticity of Substitution technology. A system of factor demand equation is derived and specified in the model. This relates the demand for each primary factor to industry outputs and prices of each of the primary factors (labor, capital, land, and intermediate inputs). This reflects the assumption 
that factors of production may be substituted for one another in ways that depend on factor prices and on the elasticities of substitution between the factors.

- Users of commodities which include industries, households, investors, government sectors form a system of demand equations. This demand system for each of these users consists of three layers (nested demand system). Consumers/users choose the optimal combination of domestically-produced and imported commodities. The last layer is they choose the optimal combination of different commodities responding the prices and budget constraints that they face. For household, a Linear Expenditure Demand System (LES) is specified.

- The household supplies of skilled and unskilled labor as well as capital and land.

- A distinction between four kinds of labor: agricultural labor, manual/production worker, clerical workers, and managerial workers. These are are 'nested' within the industry production functions. In each industry, all kind of labor enter a CES production function to produce 'labor', which itself enters a further CES production function for industry output.

- A set of export demand functions, indicating the elasticities of foreign demand for Indonesia's exports to the rest of the world.

- Rates of import tariffs and excise taxes across commodities, rates of business taxes, value added taxes and corporate income taxes across industries, and rates of personal income taxes across household types which reflect the structure of the Indonesian tax system

- A set of macroeconomic identities which ensures that standard macroeconomic accounting conventions are observed.

In general, the demand and supply equations for private-sector agents are derived from the solutions to these agents microeconomic optimization problems (cost minimization for firms and utility maximization for households). The agents are assumed to be price-takers, with producers operating in competitive markets with zero profit conditions, reflecting the assumption of constant returns to scale.

The unique feature of INDONESIA-E3 model which is very relevant in this study is the disaggregation of household by expenditure classes which allows for precise estimates of the distributional impact and poverty incidence. In the literature of the poverty impact analysis using CGE models, this class of model is called an integrated CGE model (Bourguignon, Robilliard, \& Robinson, 2003). This class of model normally has disaggregated households which link each of the households to both sources of income (through market of factors of production) and expenditure (through market for commodities). This should be distinguished from other class of model which is called top-down, where the CGE model is separate from the poverty module, and between them is only one directional relationship. In the integrated model, there is no separation between CGE model and poverty module because all are in one model. 
INDONESIA-E3 has been used in various research for example to analyze the distributional impact of fuel pricing reform (Yusuf \& Resosudarmo, 2008); the poverty and distributional impact of carbon tax (Ministry of Finance Republic of Indonesia, 2009); greenhouse gasses emission from land use change (Warr \& Yusuf, 2011). More detailed exposition of the model can be found in (Yusuf, 2008)

\section{Database construction}

Due to space limitation detailed construction of INDONESIA-E3's database including all the steps and assumptions can be found in (Yusuf, 2006). INDONESIA-E3 model of the current version use a Social Accounting Matrix (SAM) for its database representing Indonesian economy for the year 2008. The integration of highly disaggregated households adequate for accurate distributional analysis is made possible by constructing an Indonesian Social Accounting Matrix (SAM) which serves as the core database to the CGE model. The SAM consists of up to 175 industries, 175 commodities, and 200 households (100 urban and 100 rural households grouped by percentile of real expenditure per capita). The data used for constructing the SAM include Indonesian Input-Output Table, official SAM, and most importantly household level survey data (SUSENAS). Using a general equilibrium model with a disaggregated household sector feature makes it possible to conduct controlled experiments that focus on the effects of different economic shocks on household income, expenditure, poverty, and inequality. The model identifies two categories of households, rural and urban, each of which is divided into 100 subcategories of equal population size, with the subcategories arranged by expenditures per capita. ${ }^{4}$

To link and transmit the result of GTAP simulations into the INDONESIA-E3 model, we (1) aggregate the sectors in INDONESIA-E3 into 57 to match the sectors in GTAP and then (2) introduce the change in Indonesian exports by commodities, in the world price of imports, and in the world price of exports resulting from GTAP simulations as shocks in the INDONESIA-E3 model.

\section{RESULTS AND ANALYSIS}

Results from our GTAP simulation suggest that Indonesia is not among the countries most heavily affected by a recession in Europe. A 2 percent decline in Euro zone countries' GDP reduces Indonesia's GDP by only 0.052 percent relative to baseline. A 2 percent decline in all 27 countries members of the EU still reduces Indonesia's GDP by only 0.078 percent relative to baseline (Table 1).

4 For more on the INDONESIA-E3 model, please see Yusuf (2008). 


\begin{tabular}{|c|c|c|c|c|c|}
\hline & Euro Zone & EU & Japan & China & $\begin{array}{l}\text { EU+Japan } \\
\text { +China }\end{array}$ \\
\hline Oceania & -0.218 & -0.218 & -0.311 & -0.263 & -0.733 \\
\hline Japan & 0.150 & 0.150 & 0.101 & - & - \\
\hline China & 0.027 & 0.027 & 0.014 & -0.006 & - \\
\hline Rest of East Asia & 0.103 & 0.103 & 0.057 & -0.064 & -0.339 \\
\hline Indonesia & -0.052 & -0.052 & -0.078 & -0.069 & -0.176 \\
\hline Singapore & -0.398 & -0.398 & -0.514 & -0.092 & -0.861 \\
\hline Thailand & -0.048 & -0.048 & -0.107 & -0.326 & -0.514 \\
\hline Rest of SE Asia & -0.083 & -0.083 & -0.130 & -0.042 & -0.311 \\
\hline South Asia & 0.024 & 0.024 & 0.001 & 0.042 & 0.081 \\
\hline North America & -0.091 & -0.091 & -0.166 & -0.013 & -0.258 \\
\hline Latin America & -0.175 & -0.175 & -0.220 & -0.023 & -0.283 \\
\hline Euro Zone & - & - & - & 0.105 & - \\
\hline Rest of EU & -0.769 & -0.769 & - & 0.061 & - \\
\hline Mid East and N. Africa & -0.513 & -0.513 & -0.579 & -0.148 & -0.880 \\
\hline South Sa. Africa & -0.405 & -0.405 & -0.486 & -0.086 & -0.703 \\
\hline Rest of the world & -0.459 & -0.459 & -0.555 & 0.003 & -0.627 \\
\hline
\end{tabular}

Table 1 shows that the countries most negatively affected by a European recession are those in the Middle East and North African (MENA) region. With a 2 percent fall in the EU's GDP, MENA's GDP falls by almost 0.6 percent, an elasticity of 0.3 . Europe is the biggest importer of this region's energy and MENA countries are heavily dependent on energy exports.

In Asia, Singapore is the country most affected by a European recession because of its dependence on international trade. Japan and China, however, experience a slightly positive increase in GDP.

If China and Japan experience a recession of similar magnitude the impact on Indonesia's GDP will not be stronger than the impact of the European crisis. But the impact is disproportionate because Japan and China are single countries while the EU consists of 27 . A 2 percent decline in China's GDP causes a 0.07 percent decline in Indonesia's GDP and a similar decline in Japan's GDP causes a 0.03 percent decline in Indonesia's GDP. In other words, China's potential impact on Indonesia is almost twice that of Japan's.

The impact of recession in Japan will be felt most in Singapore, where GDP will fall 0.24 percent, and the impact of recession in China will be felt most in Thailand, where GDP will fall 0.33 percent relative to baseline. Singapore and Thailand are among the most open economies in Asia. 
In sum, a European recession of a sensible magnitude (2 percent GDP deviation relative to business as usual) working through full trade linkage (taking into account indirect trade effects through other countries as well) will not have a very large negative impact on Indonesia's GDP. The reason for this is that Indonesia's economy depends little on external trade. This does not mean that European recession will not affect the world economy to a considerable extent; other countries, like Singapore and MENA countries, will be greatly affected.

With respect to poverty in Indonesia, the impact of a recession in Europe, Japan, and China is also small. A combined 2 percent decline in GDP in Europe, Japan, and China will increase Indonesia's national poverty head count by only 0.19 percent (Table 2 ). The biggest impact will be if the recession is in either China, or all of the EU. The impact on a recession on poverty in Indonesia is small because (1) the impact on overall mean real consumption is small and (2) the impact is most strongly felt among higher income households.

As suggested in Figure 1, where percentage change in real expenditure is plotted on the percentile of expenditure per capita, the impact of recession in Europe, Japan, or China is similar. The impact increases with income status. For example, the effect of a recession in the Euro zone on real consumption of the richest 1 percent of urban households is 3 times bigger than on the poorest 1 percent. Similarly, the richest 1 percent of rural households experiences a decline in real consumption 4 times bigger than the poorest 1 percent. The result is similar in all simulations (Euro zone, EU, China, or Japan recession). The range of the ratio of the impact is between 2.3 to 2.9 for urban households, and between 3.3 to 4.4 for rural households. This suggests that the simulations have an inequality-reducing tendency.

The distributive effect discussed earlier can be explained by how recession affects (1) household income, particularly return on factors of production; and (2) the pattern of change in the household-specific consumption price index (CPI). The final effect on household real consumption is a function of those two factors.

Global recession tends to decrease the global prices of commodities. Transmitted to the Indonesian economy, this deflationary effect will tend to reduce commodity prices for domestic consumers. A careful look at how this affects households of different income status suggests that the effect is only slightly progressive if not neutral. Across all simulations, the ratio of the impact on household-specific CPI between the richest 1 percent and the poorest 1 percent is less than 1 . This suggests that the progressivity of impact arises largely from the income side. Richer households tend to experience income falls far greater than poorer households.

Figure 2, which shows the simulated impact of recession in Europe, Japan and China on real income of different factors of production, explains this. Almost all factors of production experience real decline in income; however, the biggest decline is where ownership is concentrated among higher income households. Capital income declines more than labor income, and skilled labor income declines more than unskilled labor income. This pattern of impact favors poorer households whose incomes largely depend on unskilled labor. 


\begin{tabular}{|c|c|c|c|c|c|c|}
\hline \multicolumn{7}{|c|}{$\begin{array}{l}\text { Table } 2 . \\
\text { Simulated Impact on Poverty }\end{array}$} \\
\hline & Ex-ante & Euro Zone & EU & Japan & China & $\begin{array}{c}\text { EU+Japan } \\
\text { +China }\end{array}$ \\
\hline \multicolumn{7}{|l|}{ URBAN } \\
\hline Headcount $\mathrm{P}(0), \%$ & 9.09 & 9.12 & 9.13 & 9.12 & 9.13 & 9.19 \\
\hline Poverty Gap P(1), \% & 1.43 & 1.44 & 1.44 & 1.44 & 1.44 & 1.46 \\
\hline Squared Poverty Gap P(2), \% & 0.37 & 0.37 & 0.37 & 0.37 & 0.37 & 0.38 \\
\hline Change in Poverty - $\mathrm{dP}(0)$ & & 0.03 & 0.04 & 0.03 & 0.04 & 0.10 \\
\hline Change in Poverty Gap - dP(1) & & 0.01 & 0.01 & 0.01 & 0.01 & 0.03 \\
\hline Change in Sq-Pov. Gap - dP(2) & & 0.00 & 0.00 & 0.00 & 0.00 & 0.01 \\
\hline \multicolumn{7}{|l|}{ RURAL } \\
\hline Headcount $P(0), \%$ & & 15.67 & 15.69 & 15.69 & 15.69 & 15.87 \\
\hline Poverty Gap P(1), \% & 15.59 & 2.52 & 2.52 & 2.52 & 2.52 & 2.55 \\
\hline Squared Poverty Gap P(2), \% & 2.51 & 0.65 & 0.65 & 0.65 & 0.65 & 0.66 \\
\hline Change in Poverty - $\mathrm{dP}(0)$ & 0.65 & 0.08 & 0.10 & 0.10 & 0.10 & 0.28 \\
\hline Change in Poverty Gap - dP(1) & & 0.01 & 0.02 & 0.02 & 0.02 & 0.04 \\
\hline Change in Sq-Pov. Gap - dP(2) & & 0.00 & 0.00 & 0.00 & 0.00 & 0.01 \\
\hline \multicolumn{7}{|l|}{ TOTAL } \\
\hline Headcount $P(0), \%$ & & 12.41 & 12.42 & 12.42 & 12.42 & 12.54 \\
\hline Change in Poverty - $d P(0)$ & & 0.05 & 0.07 & 0.06 & 0.07 & 0.19 \\
\hline \multicolumn{7}{|l|}{ DECOMPOSITION-URBAN } \\
\hline Unskilled labor & 12.35 & -11.49 & -14.20 & -13.57 & -10.97 & -37.20 \\
\hline Skilled labor & & -6.96 & -8.56 & -7.14 & -6.29 & -21.18 \\
\hline Capital & & -8.52 & -9.94 & -9.72 & -7.97 & -26.53 \\
\hline Land & & -0.79 & -1.00 & -1.05 & -0.84 & -2.75 \\
\hline Others & & -0.86 & -1.03 & -0.96 & -0.75 & -2.64 \\
\hline Total & & -28.62 & -34.73 & -32.43 & -26.81 & -90.31 \\
\hline Saving & & -4.80 & -5.83 & -5.44 & -4.50 & -15.16 \\
\hline Consumption & & -23.82 & -28.90 & -26.99 & -22.31 & -75.15 \\
\hline Living cost & & -19.97 & -23.99 & -22.73 & -17.51 & -61.82 \\
\hline Real expenditure & & -3.85 & -4.91 & -4.26 & -4.80 & -13.33 \\
\hline$\%$ chg in real expenditure & & -0.10 & -0.12 & -0.11 & -0.12 & -0.34 \\
\hline \multicolumn{7}{|l|}{ DECOMPOSITION-RURAL } \\
\hline Unskilled labor & & -12.44 & -15.27 & -14.53 & -11.69 & -39.86 \\
\hline Skilled labor & & -1.80 & -2.22 & -1.80 & -1.59 & -5.41 \\
\hline Capital & & -9.06 & -10.57 & -10.34 & -8.47 & -28.23 \\
\hline Land & & -0.84 & -1.06 & -1.11 & -0.89 & -2.93 \\
\hline Others & & -0.49 & -0.58 & -0.54 & -0.42 & -1.48 \\
\hline Total & & -24.63 & -29.70 & -28.32 & -23.06 & -77.91 \\
\hline Saving & & -1.35 & -1.63 & -1.55 & -1.26 & -4.26 \\
\hline Consumption & & -23.28 & -28.08 & -26.77 & -21.80 & -73.64 \\
\hline Living cost & & -18.82 & -22.65 & -21.26 & -16.39 & -58.03 \\
\hline Real expenditure & & -4.46 & -5.43 & -5.51 & -5.41 & -15.61 \\
\hline$\%$ chg in real expenditure & & -0.10 & -0.13 & -0.13 & -0.13 & -0.37 \\
\hline
\end{tabular}


Percentile of expenditure per capita

Real Expenditure (\%chg)

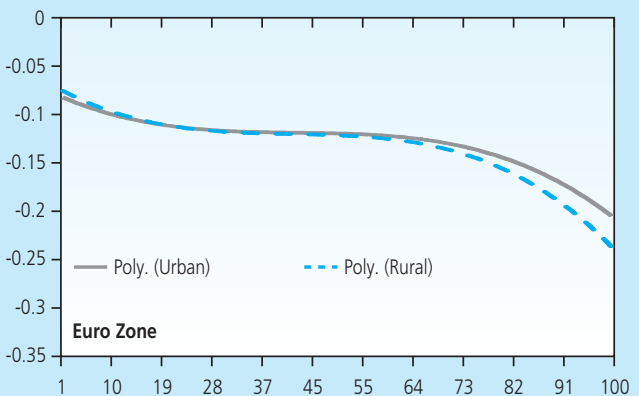

Percentile of expenditure per capita Real Expenditure (\%chg)

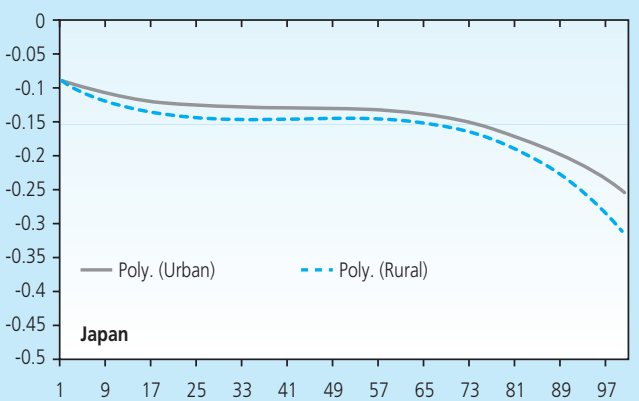

Percentile of expenditure per capita

Real Expenditure (\%chg)

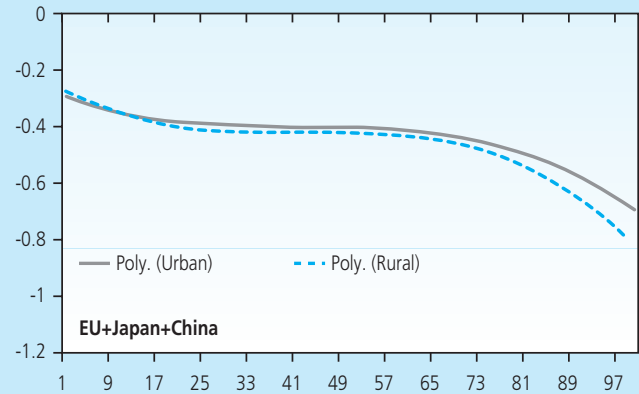

Source: Author's calculation based on simulation with INDONESIA-E3 model.
Percentile of expenditure per capita

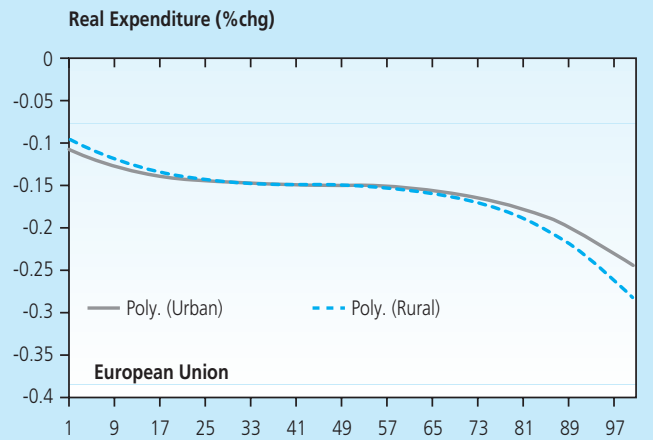

Percentile of expenditure per capita Real Expenditure (\%chg)

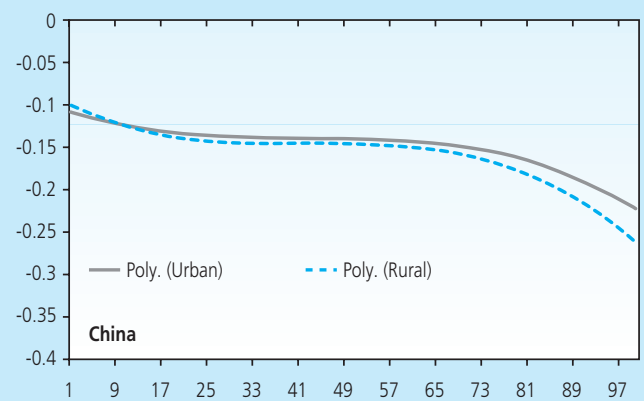

Graphic 1.

Simulated Impact on Real Consumption by Household Groups 
Euro Zone

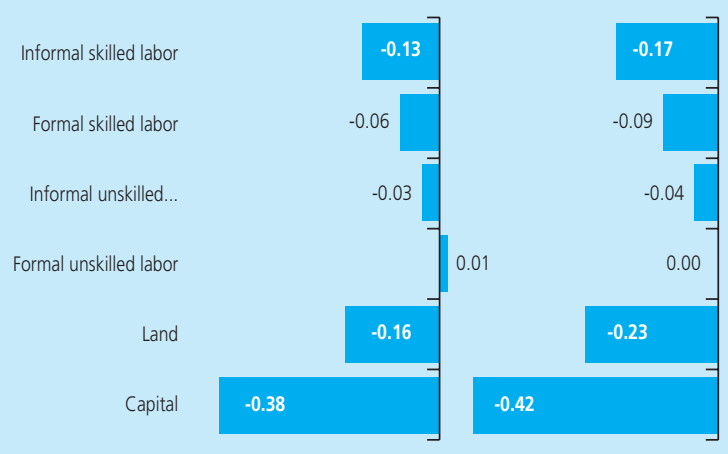

Japan

China

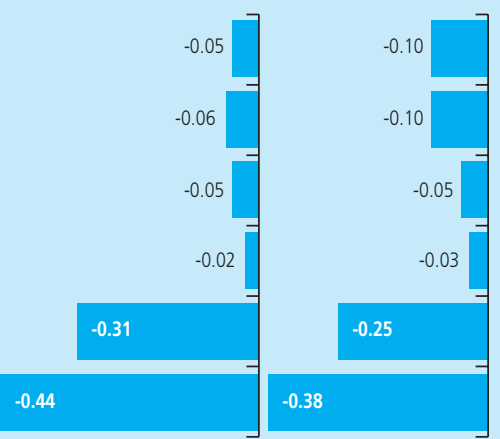

SOURCE: Author's calculation based on simulation with INDONESIA-E3 model.

Figure 2.

Simulated Impact on Real Income of Factors of Production

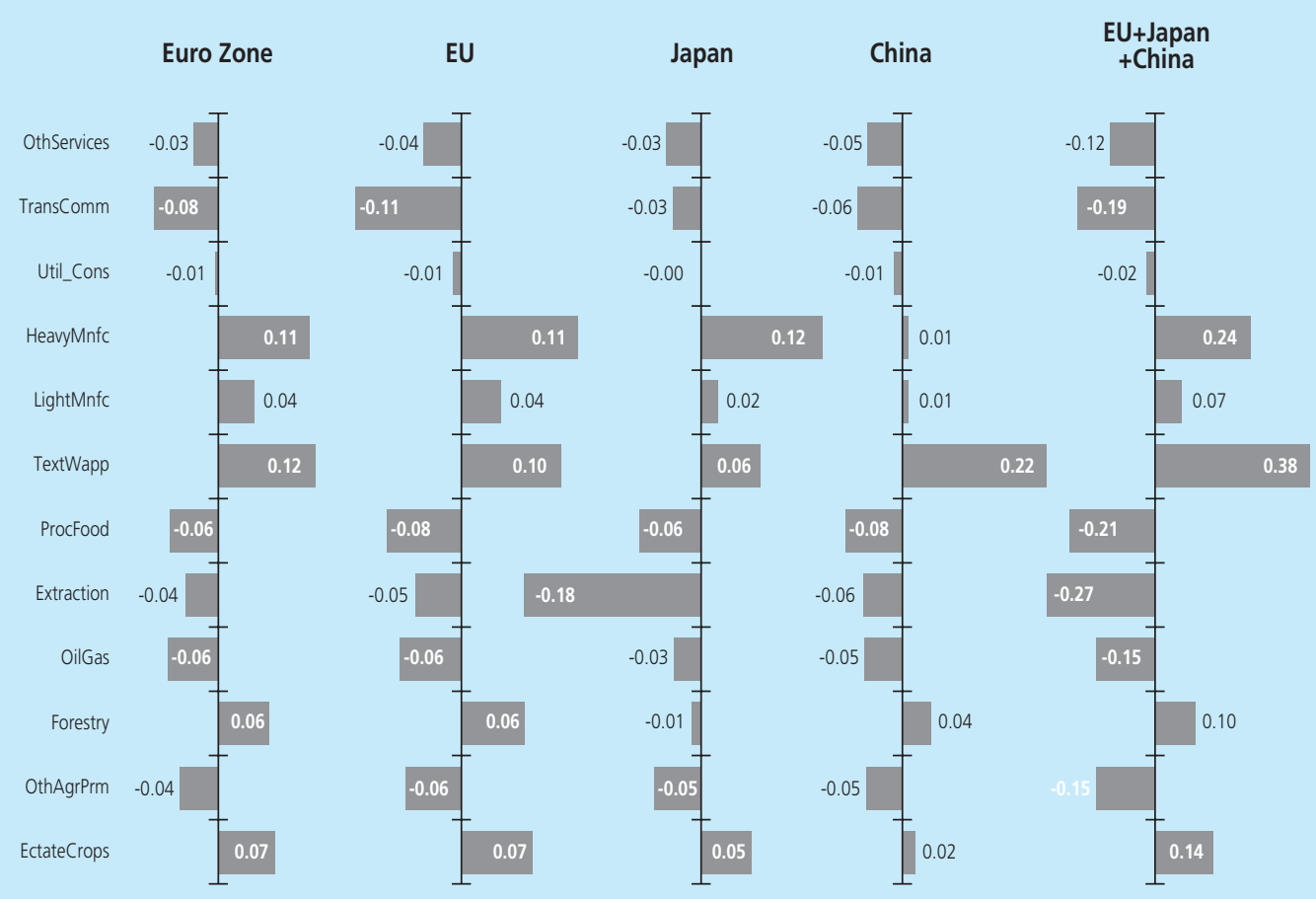

SOURCE: Author's calculation based on simulation with INDONESIA-E3 model.

Figure 3.

Simulated Impact on Output of Aggregated Sectors (\% change from baseline) 
The pattern of impact on production factors income is largely driven by how industries respond to trading partners' recession. As shown in Figure 3, the simulated recession in Europe, Japan, and China negatively affects output in certain sectors, most notably oil, gas, and other extractive sectors. These sectors are capital- and skill-intensive. Figure 4 shows how the contraction and expansion of output is correlated with changes in exports of those sectors.

A closer look at the impact on poverty suggests that rural areas would be harder hit than urban areas (Table 2). For example, a recession in Europe, Japan, and China combined would increase the incidence of poverty in urban areas by 0.10 percent and in rural areas by 0.28 percent. To understand this, we examine what happens to real consumption in marginally poor urban and rural households. A marginally poor household is one whose expenditure per capita is closest to the poverty line. Knowing what happens to these households shows how the simulation affects poverty incidence.

As explained in Warr, Menon, and Yusuf (2012), The basis for the decomposition is as follows. We focus on the sources of changes in the real expenditure of a particular household, say household $h$, arising from some external shock. Upper case Roman letters, like $Z$, will denote levels of variables and lower case Roman letters, like $z$, will denote their proportional change, so that $z=d Z / Z$. The levels of nominal income and nominal expenditure of household $h$ will be denoted $Y_{h}$ and $E_{h}$, respectively. Let the proportional change in the nominal expenditure of household $h$, be $e_{h}=\widetilde{e}_{h}+p_{h}$, where $\tilde{e}_{h}$ is the proportional change in the household's real expenditure and $p_{h}=\sum_{i=1}^{I} \varepsilon_{h}^{i} p^{i}$ is the proportional change in a consumer price index specific to household $h$, with $\varepsilon_{h}^{i}=E_{h}^{i} / E_{h}$ denoting that household's expenditure share on commodity $i, E_{h}^{i}$ denoting its nominal expenditure on commodity $i$ and $p^{i}$ denoting the proportional change in the consumer price of commodity $i$.

The absolute change in this household's nominal expenditure is now

$$
d E_{h}=E_{h} e_{h}=E_{h}\left(\widetilde{e}_{h}+p_{h}\right)=d \widetilde{E}_{h}+E_{h} p_{h}=d \widetilde{E}_{h}+\sum_{i=1}^{I} E_{h}^{i} p^{i}
$$

That is, the change in nominal expenditure of the household is given by the change in its real expenditure plus the change in its true cost of living, the latter an expenditure weighted sum of the changes in the consumer prices that household actually faces, where the expenditure weights pertain to that particular household. ${ }^{5}$ The change in nominal expenditure is also equal to the change in nominal income minus the change in saving, so that $d E_{h}=d Y_{h}-d S_{h}$. Disregarding any changes in transfer income or direct taxes, for simplicity, the change in nominal income is equal to the change in nominal factor income, $d Y_{h}=d Y_{h}^{f}$.

5 It should be noted that real expenditures means expenditures measured at constant prices, defined here to mean base period prices. Thus, the levels of nominal and real expenditures in the base period are identical, meaning $E_{h}=\tilde{E}_{h}$. 
Thus, rearranging terms,

$$
d \tilde{E}_{h}=d Y_{h}^{f}-d S_{h}-\sum_{i=1}^{I} E_{h}^{i} p^{i}
$$

The change in the household's real income is decomposable into three components: (i) the change in its nominal factor income minus (ii) the change in its savings minus (iii) the change in its true cost of living. Importantly, the change in nominal factor income is itself additively decomposable into its factor components, as identified in the model.

This decomposition is applied to those households are those who are in the border of poverty line. They are percentile 8 household in urban area and the percentile 15 in rural area. What happens to these two representative households may explain what happens to poverty incidence.

As shown in Table 2, the percentage change in the real expenditure of marginally poor households in urban and rural areas does not differ much. For the combined simulations, for

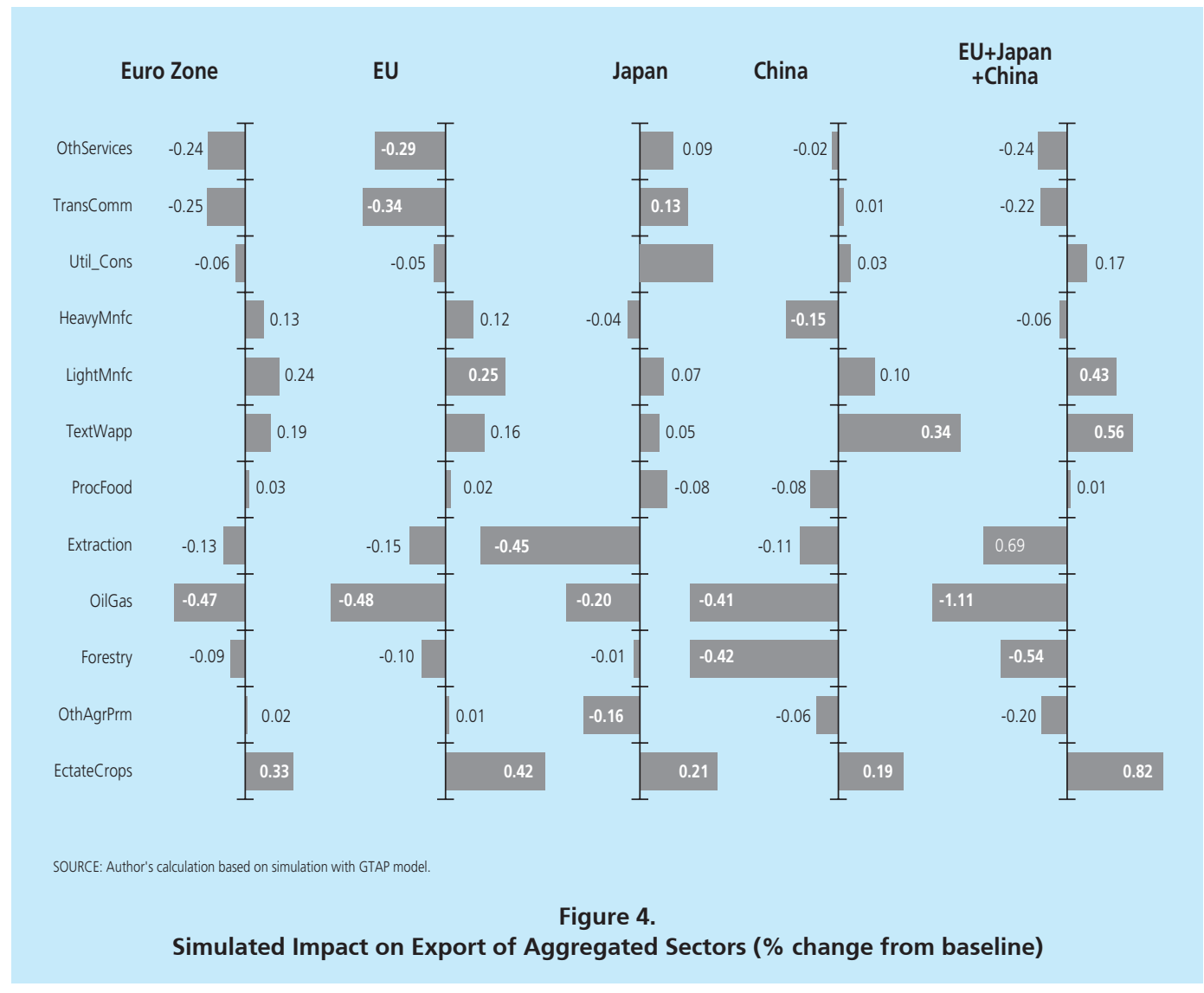


example, marginally poor households in urban areas experience a 0.34 percent decline in real consumption while those in rural areas experience a 0.37 percent decline. This much larger impact on poverty incidence in rural areas suggests that the elasticity of poverty incidence with respect to the change in the real consumption of marginally poor households is relatively larger. The slope of the cumulative distribution function (CDF) of the real consumption of the rural households around the region of the poverty line must be higher than that of urban households. With the same magnitude of change in their consumption, the rural poor are more vulnerable to external shocks than urban households.

It is also useful to understand to what extent change in the real expenditure of the marginally poor household is driven by its decomposable drivers. The decline in the real expenditure of the poor can be generally decomposed into income effect (decline in income) and consumer price effect (increase in the price of the commodity basket of the poor or living cost). The income effect can also be decomposed (e.g., labor income, capital income). Table 2 shows how it is the case for urban and rural marginally poor households. Several conclusions can be drawn from this decomposition exercise.

First, the poverty-increasing effects come only from the income side. Poverty increases because the income of the poor decreases, not because of a rise in inflation or the cost of living. Global recession, ceteris paribus, is deflationary and as shown in Table 2, the cost of living for the poor actually falls. Second, the fall in income of the poor is largely the result of a fall in unskilled labor income. As our earlier discussion suggests, income from unskilled labor falls the least as compared to other factor income in aggregate, but this income makes up the dominant share of the poor's income. Third, despite a decline in the cost of living, the real consumption of the poor falls because the decline in income cannot be compensated for. As a result, poverty increases in urban and rural areas.

\section{v. CONCLUSION}

The effect of a recession in Europe, Japan and China on other economies through trade linkage depends on many factors. These factors include the importance of bilateral trade between the affected countries or regions, the openness of the economy, and the country's level of diversification in export commodities and trading partners.

The impact on poverty in the affected countries depends even more on various country specific aspects such as how the poor earn its income and how the spend their earning. If bigger part of its source of income are affected by the global crisis and the price of the commodities they intensively consumed are heavily affected, then the poor will be vulnerable to external shocks. This is empirical and this paper touch this important issue.

This paper shows that the impact of a recession in Europe, Japan, or China on Indonesia is relatively small simply because Indonesia is a relatively less open economy and depends 
predominantly on its domestic market. According to our analysis, the current recession in Europe, Japan and China will have only a small negative effect on Indonesia's GDP and poverty rate.

However, results suggest that it would be wise to pay attention to China. According to our simulation, a recession in China could reduce Indonesia's GDP two times more than a recession of similar magnitude in Japan.

This analysis shows that a recession in Europe, Japan, and China would have its largest negative impact on richer households in Indonesia. Richer households would suffer the most because their incomes are largely dependent on the capital- and skill-intensive sectors of the economy. With respect to the poor, our analysis suggests that a recession in Europe, Japan or China will not have much of an impact on prices in Indonesia. In other words, the cost of the living of the poor will not be much affected. Policymakers in Indonesia should therefore concentrate less on pricing policies and more on employment policies to protect the poor from loss of employment. Since they are less skilled, the poor are likely to be the first to lose their jobs in the event of a recession.

Finally, our analysis does not cover the effects of recession in Europe, Japan and China on economic channels other than trade, such as foreign direct investment and the financial sector. The general equilibrium model used in our analysis does not cover the financial sector, so other studies focusing on this channel are warranted. In addition, in the longer term, poverty is affected by various factors other than income and prices. Human capital accummulation, sosial assitance policies and equality of opportunity are important in poverty alleviation. This effects are not accounted for in this analysis. 


\section{REFERENCES}

Ahmed, V., \& Donoghue, C. O. (2010). Global Economic Crisis and Poverty in Pakistan. International Journal of Microsimulation, 3(1), 127-129. Retrieved from http:// microsimulation.org/IJM/N3_1/IJM_36.pdf

Ajwad, M. I., Francisco, H., \& Azam, M. (2012). Simulating The Impact of the 2009 Financial Crisis on Welfare in Latvia.

Bibi, S., Cockburn, J., Emini, C. A., Fofana, I., Ningaye, P., \& Tiberti, L. (2010). Impact of the Global Economic Crisis on Child Poverty in Cameroon and Options for a Policy Response. Italy.

Bourguignon, F., Robilliard, A.-S., \& Robinson, S. (2003). Representative Versus Real Households in the Macro-Economic Modelling of Inequality. Paris.

Brockmeier, Martina (2001). A Graphical Exposition of the GTAP Model. GTAP Technical Papers (No. 8).

Corong, E., \& Taningco, A. (2011). Global Economic Crisis and the Philippine Economy: A Quantitative Assessment.

Coxhead, I., Linh, V. H., \& Tam, L. D. (2012). Global Market Shocks and Poverty in Vietnam: The Case of Rice. Agricultural and Applied Economics, 43(5), 575-592.

Estrades, C., \& Llambi, C. (2013). Lessons from the 2008 Financial Crisis: Policy Responses to External Shocks in Uruguay. The Developong Economies, 51(3), 233-259.

Habib, B., Narayan, A., Olivieri, S., \& Sanchez-Paramo, C. (2010a). Assessing Ex Ante the Poverty and Distributional Impact of the Global Crisis in a Developing Country (No. 5238). Washington DC.

Habib, B., Narayan, A., Olivieri, S., \& Sanchez-Paramo, C. (2010b). Assessing Poverty and Distributional Impacts of the Global Crisis in the Philippines (No. 5286).

Hertel, T. (1997). Global Trade Analysis: Modeling and Applications. Cambridge and New York: Cambridge University Press.

Ministry of Finance Republic of Indonesia, M. o F. (2009). Economic and Fiscal Policy Strategies on Climate Change: Indonesian Green Paper. Jakarta

Narayanan, Badrie, G., \& Walmsley, T. L. (2008). Global Trade, Assistance, and Production: The GTAP 7 Data Base (8th ed.). Center for Global Trade Analysis, Purdue University. Retrieved from http://www.gtap.agecon.purdue.edu/databases/v7/v7_doco.asp 
Warr, P., \& Yusuf, A. A. (2011). Reducing Indonesia's Deforestation-Based Greenhouse Gas Emissions. Australian Journal of Agricultural and Resource Economics, 55(3), 297-321. http://doi.org/10.1111/j.1467-8489.2011.00540.x

Weeks, J. (2009). The Impact of the Global Financial Crisis on the Economy of Sierra Leone. International Policy Centre for Inclusive Growth, 18, 138-152.

Wong, S. (2012). Short-term Macroeconomic and Poverty Impacts of the Global Economic Crisis on the Ecuadorian Economy.

Yusuf, A. A. (2006). Constructing Indonesian Social Accounting Matrix for Distributional Analysis in the CGE Modelling Framework (No. 200604).

Yusuf, A. A. (2008). An Indonesian Applied General Equilibrium Model for Analyzing the Economy, Equity, and the Environment (No. 200804).

Yusuf, A. A., \& Resosudarmo, B. P. (2008). Mitigating Distributional Impact of Fuel Pricing Reform: Indonesian Experience. ASEAN Economic Bulletin, 25(1), 32-47. Retrieved from http://www.jstor.org/stable/41231493 
228 Buletin Ekonomi Moneter dan Perbankan, Volume 18, Nomor 2, Oktober 2015

Halaman ini sengaja dikosongkan 